\title{
Kombinasi Pendekatan Pembelajaran Musik Berkonsep Barat dan Kearifan Lokal Bagi Peserta PPL
}

\author{
Diah Latifah \\ Universitas Pendidikan Indonesia Bandung \\ Jl. Setiabudi - Bandung
}

\begin{abstract}
This study analises the learning method model with western approach concept and Local wishdom concept in the music learning that was conducted by Teaching Practice participants. The objective of this sudy is to find out the strength of both western and local whisdom music learning approach to prepare competence music teachers. The research method used is narative enquiry to explain various observed events happened during the research. The result of the research shows, that combination of local wishdom concept and western concept of music learning approach have strength to create the participants of teaching practise to be candidates of a profesional music teacher who has fine competence in teaching music, and fine soft skill when conducting implementation of learning. The result of music learning achieved by the students provides significant information. The Students have a good music competence as well as soft skill competence resulted from music learning process.
\end{abstract}

Keywords: Combination of Local Wisdom concept and Western concept of music learning approach, competence music teacher candidate

\begin{abstract}
ABSTRAK
Kajian ini menganalisis model pendekatan pembelajaran dengan konsep Barat dan Kearifan Lokal pada pembelajaran musik yang dilaksanakan oleh peserta Program Pengalaman Lapangan. Tujuan kajian adalah untuk mengetahui kekuatan pendekatan pembelajaran berkonsep Barat dan kearifan lokal untuk mempersiapkan calon guru musik berkompeten. Metode penelitian yang digunakan adalah Narratif Inquiry untuk menjelaskan berbagai kejadian yang diobservasi pada saat penelitian berlangsung. Hasil penelitian mengungkap, bahwa kombinasi pendekatan pembelajaran berbasis kearifan lokal dan berkonsep Barat memiliki kekuatan untuk mengantarkan peserta Program Pengalaman Lapangan sebagai calon guru musik professional yang memiliki kompetensi mengajar musik dengan baik, serta soft skill saat melaksanakan implementasi pembelajaran. Hasil belajar musik yang dicapai siswa memberikan informasi yang signifikan. Siswa memiliki kompetensi musik yang baik disertai dengan kompetensi soft skill hasil dari proses belajar musik.
\end{abstract}

Kata kunci: Kombinasi Pendekatan Pembelajaran Berbasis Kearifan Lokal dan berkonsep Barat - Calon guru musik berkompeten 


\section{PENDAHULUAN}

Program Pengalaman Lapangan atau Praktik Pengalaman Lapangan yang akronimnya PPL, adalah bentuk praktek kerja lapangan yang mempersiapkan para calon guru untuk menjadi guru berkompeten. Widiastuti (2013) mengungkapkan:

Praktik Pengalaman Lapangan (PPL) merupakan salah satu komponen kurikuler yang memerlukan keterpaduan antara penguasaan materi dan praktik. Disamping itu, PPL merupakan salah satu kegiatan akademik yang bersifat intrakurikuler yang mencakup latihan mengajar dan tugas-tugas kependidikan lainnya secara terbimbing, terarah dan terpadu untuk memenuhi persyaratan pembentukan tenaga profesional dalam kependidikan.

Program Pengalaman Lapangan dilaksanakan melalui pendidikan pengalaman mengajar, dalam penelitian ini mengajar seni musik dengan bimbingan guru pamong serta dosen pembimbing. Berbasis pengalaman pada pendidikan seni menurut Jazuli (2008:70) “Pengalaman estetik merupakan pengalaman tentang keindahan". Untuk melaksanakan kegiatan pembelajaran musik yang mengasah rasa estetik dibutuhkan kegiatan kreatif yang dilaksanakan melalui apresiasi. Jazuli (2008:70 mengutarakan “Untuk dapat mencapai pengalaman estetik perlu suatu cara yakni melalui kegiatan apresiasi dan kreasi". Kegiatan ini akan memperluas pemahaman siswa, mengenal, memahami dan mempraktikan ilmu seni serta membuka wawasn seni yang meluas kembali Jazuli (2008:70) menyatakan:

Pengalaman estetik merupakan pengalaman tentang keindahan: bagaimana menghayati nilai nilai keindahan atau bagaimana keindahan itu dimaknai melalui penginderaan. Pengalaman estetik dapat dikatakan sebagai jantung kehidupan seni-jagat seni lekat dengan persoalan nilai-nilai keindahan yang melibatkan olah hati (karsa, etika), olah cipta (logika), olah rasa (emosi dan estetika), dan olah raga (fisik, kinestetika) manusia.

Dalam pernyataan di atas tampak bahwa demikian besar nilai pengalaman estetik dalam olah hati, cipta, rasa, dan olah raga. Dalam dunia pendidikan dan pembelajaran, aspek pengolahan estetik memiliki aspek dasar teori kognitif Benyamin Bloom yang mengembangkan sisi afektif berupa olah hati dan rasa, kognitif merupakan olah cipta dan logika, serta psikomotor berbasis olah fisik dan kinestetik.

Dalam dunia pendidikan berbasis kearifan lokal, teori kognitif di atas memiliki makna yang setara dengan ungkapan silih asih, silih asah, dan silih asuh. Elvinaro dalam Latifah (2014) mengungkapkan: "Filsafat Sunda lainnya, "Silih Asah, Silih Asuh dan Silih Asih," kalau dianalogikan kepada ilmu pengetahuan adalah ilmu tentang sikap yang dikembangkan oleh psikologi Barat, yakni sikap itu terdiri dari asah (kognisi), asih (afeksi) dan asuh (psikomotor)". Regelski dalam Latifah (2014) mengungkapkan kesetaraan landasan berpikir kearifan lokal di atas dalam disiplin ilmu pendidikan Barat.

"bahwa kompetensi musik, diawali dengan aspek afektif, berupa rasa, sikap dan nilai, yang diarahkan pada aspek pengetahuan berupa pemahaman musik secara komprehensif baik secara praktis ataupun teoritis, dan dalam waktu yang bersamaan juga menghasilkan kompetensi ketrampilan memainkan karya musik. Keseluruhan proses dimungkinkan oleh motivasi dari pengajar".

Gambar yang menyatakan pemaknaan teori pendidikan Barat bersesuaian dengan kearifan Lokal Sunda tergambar di atas.

Penggunaan pendekatan pembelajaran bagi peserta Program Pengalaman Lapangan atau PPL memiliki makna penting 


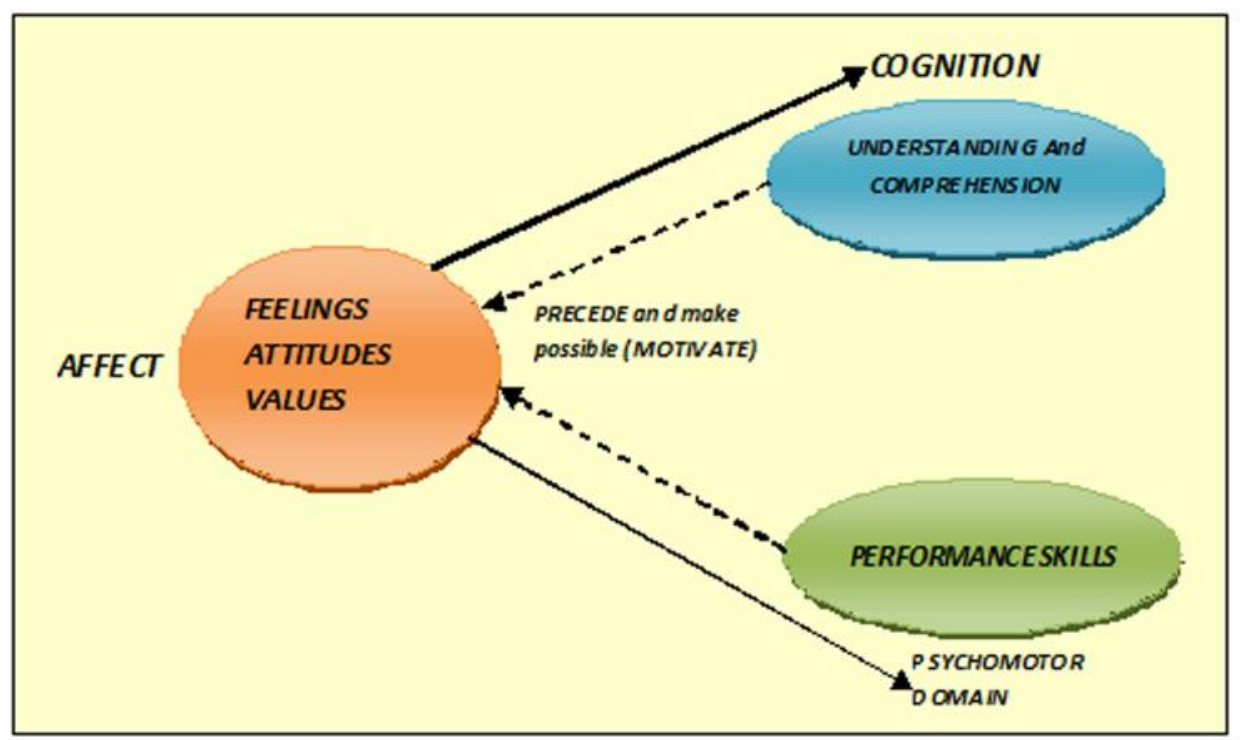

Gambar 1. Feelings, Attitudes, and Values

Sumber: Regelski Dalam Latifah (2014: 49)

bagi implementasi pembelajaran yang dilaksanakan, karena pendekatan pembelajaran merupakan cara pandang seseorang untuk melaksanakan implementasi pembelajaran sesuai dengan landasan konseptual yang kemudian diimplementasikan. Sanjaya (2008:127) mengungkapkan "Pendekatan dapat diartikan sebagai titik tolak atau sudut pandang kita terhadap proses pembelajaran." Sudut pandang dapat dimaknai dengan suatu konsep pembelajaran yang digunakan untuk mengimplementasikan satu proses pembelajaran. Pendekatan pembelajaran yang diimplementasikan dalam pembelajaran dapat menggunakan lebih dari satu konsep, karena suatu sudut pandang dalam implementasi pembelajaran berkemungkinan memiliki beberapa acuan konseptual yang melatari suatu implementasi pembelajaran.

Pendekatan pembelajaran yang digunakan dalam Program Pengalaman Lapangan atau PPL mapel Seni Budaya bidang Musik di sekolah formal dalam kajian ini tingkat SMA, memiliki keunikan karena implementasi pembelajaran musik yang dilaksanakan memiliki karakter bernuansa kearifan lokal berbasis budaya bangsa, sehingga pendekatan pembelajaran yang digunakan merupakan penyatuan antara pendekatan pembelajaran dari ranah konsep Barat dan konsep Kearifan Lokal. Pendekatan pembelajaran dalam tradisi Barat, banyak digunakan dalam proses pembelajaran di sekolah formal, baik tingkat pendidikan dasar maupun di tingkat menengah.

Sesuai dengan sifatnya, pembelajaran musik sarat dengan muatan afektif, dan kegiatan musik merupakan kegiatan praktik musik ekspresif dan kreatif, maka pendekatan pembelajaranya pun sesuai dengan karakter tersebut. Beberapa pendekatan yang baik dalam pembelajaran seni musik di antaranya, pendekatan berbasis pengalaman, apresiatif, aktif, kooperatif untuk ensambel musik serta kegiatan kreatif bagi aransemen dan penciptaan musik. Pembelajaran aktif menurut Kährika, Pille, 
Äli Leijena,b, ${ }^{*}$, Tuulike Kivestua, (2012) memiliki keunggulan dalam implementasi kurikulum pendidikan musik

The reformed upper secondary school curriculum in Estonia states that pupils need to be supported to take a more active role when developing knowledge and competencies in music. The purpose of the current study was to test an active learning method designed to support music listening skills.

Pernyataan ini menyatakan bahwa hendaknya guru memberi dorongan untuk belajar lebih aktif ketika mengembangkan pengetahuan dan kompetensi musik. Sasaran dari studi yang dilaksanakan adalah untuk menguji metode belajar aktif mendukung keterampilan pendengaran musik. Seperti kita pahami, bahwa sensitivitas pendengran dalam dunia musik adalah suatu hal mendasar. Selanjutnya Scott, Sheila (2011:94) mengungkap:

Active learning as a descriptor fits well with music education in which students are involved in making music-for example, singing, playing instruments, improvising, composing, and listening to music performed by themselves or others (in real time or recorded form).

Bermakna, belajar aktif adalah deskriptor, sesuai dengan pendidikan musik di mana siswa terlibat dalam membuat musik, contohnya, menyanyi, bermain instrumen, berimprovisasi, menyusun komposisi, dan mendengarkan pertunjukan musik yang dilakukan sendiri atau orang lain melalui rekaman. Dengan kekuatan ini belajar aktif memiliki keunggulan untuk menguatkan kemanpuan musik secara secara variatif, dan sistemik. Kembali Scott, Sheila (2011:95) mengungkapkan:

An analytic stance toward active learning is associated with deep approaches to understanding: students are engaged actively in their learning by interpreting new information in terms of what they already know and mediating this learning through their interactions with others (Buckland 2001; Burnett and Romina 2002)

Bermakna dalam analisisnya, belajar aktif berasosiasi dengan pendekatan mendalam menuju pemahaman: siswa ikut serta secara aktif dalam belajarnya melalui intrepretasi informasi baru, dalam istilah apa yang telah mereka ketahui dan memediasi belajar melalui interaksi mereka dengan yang lain. Berinteraksi dengan yang lain dalam pendidikan memiliki keterkaitan dengan proses belajar bersama dalam ranah pendekatan Cooperatif Learning.

Slavin dalam Sharan, (2012:7) mengenai Cooperatif Learning mengungkapkan “Tujuan utama dari Kelompok Belajar Siswa adalah mempercepat pemahaman semua siswa. Metode Kelompok Belajar Siswa sudah banyak dievaluasi dan secara konsisten dinyatakan efektif berdasar penelitian yang diawasi dengan baik di sekolah-sekolah umum regular". Pernyataan ini mengungkapkan bahwa belajar secara berkelompok akan mempercepat pemahaman siswa akan pembelajaran yang disampaikan, memberikan hasil efektif dalam prosesnya. Sharan (2012:6) mengutarakan "Gagasan utama d belakang STAD (Students Teams-Achievements Divisions) adalah memacu siswa agar saling mendorong dan membantu satu sama lain untuk menguasai keterampilan yang diajarkan guru". Belajar bersama memiliki kekuatan untuk siswa agar saling mendorong dan memacu agar menguasai materi yang diberikan guru. Slavin (2008:10) selanjutnya mengutarakan "Semua metode pembelajaran kooperatif menyumbangkan ide bahwa siswa yang bekerja sama dalam belajar dan bertanggung jawab terhadap teman satu timnya mampu membuat diri mereka belajar sama baiknya". Artinya, kalau siswa 
belajar secara kooperatif mereka akan melalui proses pembelajaran sama baiknya. Dengan paparan ini, hasil pembelajaran akan membuahkan prestasi yang baik pula.

Dalam paparan diatas, diungkapkan bahwa pembelajaran aktif, kooperatif, kreatif, dan apresiatif serta berbasis pengalaman, didukung teori kognitif serta aplikasi konsep kearifan lokal, memiliki keutamaan dan keunggulan dalam pembelajaran musik. Akan tetapi penulis masih belum yakin, sebelum terdapat pengujian bahwa paparan konseptual di atas efektif dipergunakan dalam proses pembelajaran musik. Maka ditarik permasalahan:

a. Apakah kombinasi pendekatan pembelajaran dengan konsep Barat dengan Kearifan Lokal memiliki kemampuan untuk mengantarkan pembelajaran musik dengan baik pada siswa?

b. Apakah kombinasi pendekatan pembelajaran dengan konsep Barat dengan Kearifan Lokal memiliki kemampuan untuk memperkuat kompetensi calon guru musik peserta PPL dalam aspek penggunaan pendekatan pembelajaran?

Pembatasan kajian dalam penelitian ini; kearifan lokal dalam pendidikan musik, hanya dibatasi oleh kearifan lokal tatar Sunda. Pembatasan masalah kajian Pendekatan Pembelajaran Konsep Barat adalah belajar aktif, kooperatif, berbasis pengalaman, apresiatif, dan kreatif.

\section{METODE}

Metode penelitian yang dilaksanakan berupa Naratif Inquiry, menjelaskan berbagai kejadian dan proses penelitian sesuai dengan tujuan kajian. Penjelasanpenjelasan diapaparkan dengan jelas tidak direkayasa apa adanya, bersifat fenomenologis dalam kurun waktu tertentu.

Desain penelitian menggambarkan, penggunaan pendekatan pembelajaran berkonsep barat dan penggunaan pen-

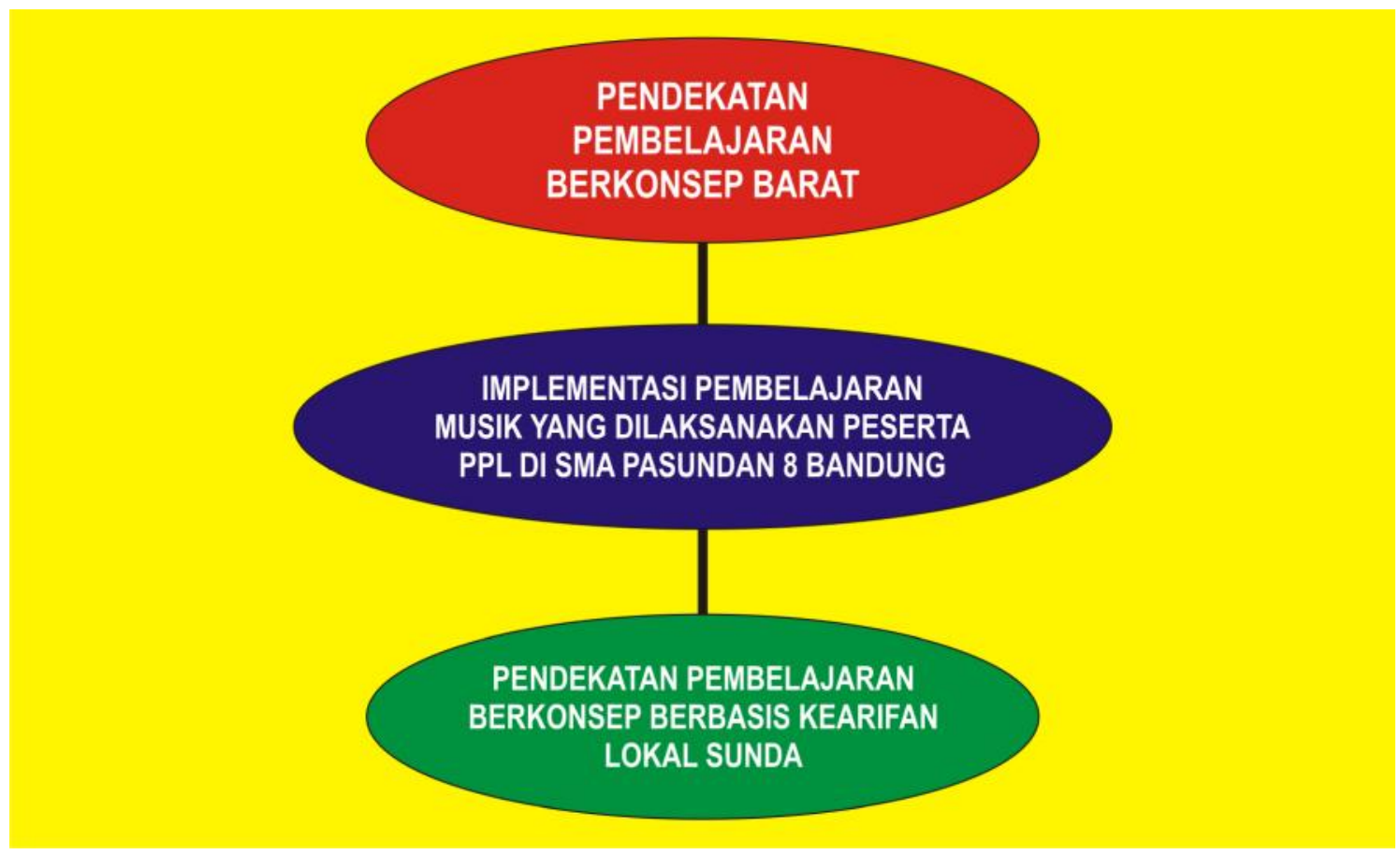

Gambar 2.

Desain Penelitian: Kajian Kombinasi Pendekatan Pembelajaran

Konsep Barat dengan Kearifan Lokal Pada Pembelajaran Musik 
dekatan pembelajaran berkonsep kearifan lokal pada implementasi pembelajaran musik yang dilaksanakan para peserta PPL. Implementasi pembelajaran musik dilaksanakan dua orang responden yaitu dua orang peserta PPL yang menggunakan dua pendekatan tersebut pada implementasi pembelajaran musik. Penelitian ini mengkaji kebermaknaan kombinasi penggunaan pendekatan pembelajaran yang menjadi focus penelitian terhadap implementasi pembelajaran musik yang dilaksanakan peserta PPL.

Tujuan penelitian dilaksanakan untuk memindai dan mencari informasi: keunggulan dan keterbatasan kombinasi pendekatan pembelajaran konsep Barat dan kearifan lokal, dalam pembelajaran musik bagi persiapan calon guru musik.

Instrumen Penelitian yang digunakan adalah pedomen observasi dan pedoman wawancara. Pedoman observasi digunakan untuk memindai keunggulan dan keterbatasan pendekatan pembelajaran berkonsep barat dan kearifan lokal yang digunakan peserta PPL saat mengajar mapel seni budaya bidang musik. Disamping itu pedoman observasi digunakan untuk mengamati pencapaian belajar siswa ketika belajar mapel seni budaya bidang musik dengan menggunakan pendekatan pembelajaran berkonsep barat dan kearifan lokal.

Pedoman wawancara yang diberikan pada guru pamong, untuk menarik informasi implementasi pembelajaran musik yang dilaksanakan peserta PPL dan diarahkan oleh guru pamong

Dokumentasi dilakukan dengan menggunakan VCR dan kamera, untuk mendapatkan informasi yang lebih kuat, saat pendekatan pembelajaran diimplementasikan pada proses pembelajaran mapel seni budaya bidang musik di kelas
Lokasi Penelitian di SMA Pasundan 8, jalan Cihampelas Bandung.

\section{HASIL DAN PEMBAHASAN}

Berdasarkan hasil pengamatan setiap pertemuan yang dilaksanakan, hampir seluruh siswa terlibat secara aktif dalam kegiatan musik yang diajarkan oleh para peserta Program Praktik Lapangan. Kalau terdapat satu atau dua orang yang tidak terlihat aktif, mereka nampak memiliki keterbatasan dalam penangkapan bahasa bunyi, kurang peka akan rasa ritmik, atau buta nada.

Siswa yang buta nada, mereka kesulitan untuk mengimitasi bahasa bunyi bernada, sehingga setiap menirukan bahasa bunyi yang disampaikan melalui vokal, terutama dalam materi tonalitas, interval, dan melodi, mereka menyanyikanya dengan fals. Untuk siswa dengan karakter seperti ini, para peserta Program Praktik Lapangan mengkhususkan mereka pada pemberian materi pengalaman permainan pola ritme dan birama pada suatu karya musik yang dibekalkan.

Untuk para siswa yang mengalami keterbatasan rasa ritmik, mereka lambat untuk menirukan pola ritme, dan dua orang siswa dari seluruh siswa yang belajar pola ritme, untuk menerapkan birama pertigaan sulit, masih sering salah. Mereka diminta untuk mengalami, menirukan dan mempraktikan bahasa bunyi, rasa birama dan pola ritme yang paling sederhana. Misalkan membunyikan bunyi yang bertekanan dan tidak bertekanan (arsis dan thesis) pada hitungan pertama pada birama 2/4, 4/4, atau 3./4, serta menirukan pola ritme yang tidak terlalu sulit dalam suatu karya musik yang diapresiasi melalui media audio atau audiovisual. Siswa dengan keterbatasan merasakan ritmik, 
diberi penguatan rasa ritmik dengan mempelajari pola ritme yang paling sederhana, dengan mempraktikan pola birama biner, dengan tempo lambat. Pada latihan pola ritme, mereka dibekali dengan permainan pola ritme pada nilai not penuh, nilai not setengah ketukan dan nilai not seperempat ketukan, melalui permainan pola ritme sederhana pada tempo lambat sampai sedang. Pada latihan ini mereka yang agak lambat pencerapan sensitivitas rasa ritmenya dapat belajar pola ritme secara memadai, meski tidak sebaik mereka yang berbakat rasa musik ritmis.

Para peserta Program Pengalaman Lapangan melaksanakan proses pembelajaran musik di kelas, pada mata pelajaran seni budaya bidang musik tradisi Barat, mereka selalu mempergunakan media audio atau audiovisual sebagai rangsangan awal dan sebagai kegiatan apresiasi untuk menstimulus keingin tahuan peserta didik. Respon didapatkan dengan mengadakan sesi tanya jawab, dan menggali pencerapan peserta didik akan bahasa bunyi (musik) yang mereka simak. Setelah pencerapan berbagai aspek bahasa bunyi berupa pola ritme, pola birama, tonalitas mayor atau minor, interval, pola melodi yang digali dari bahasa bunyi musik yang dibekalkan, siswa diminta untuk menirukan kembali dengan praktik vocal atau bertepuk tangan dan melang-kahkan kaki sebagai pola bahasa bunyi yang telah di sampaikan. Pada pemberian materi ansambel pola ritme, para siswa diajar langsung oleh para peserta PPL, untuk mengalami permainan musik, dengan cara praktik bertepuk tangan, memukul bangku kursi, dan membuat pola ritme berkelompok membentuk ansambel musik ritme. Dalam kegiatan ini para siswa diajak oleh pengajar peserta PPL untuk menyusun komposisi baru berbentuk komposisi pola ritme, yang dipraktikan secara berkelompok, melalui kegiatan aktif, kooperatif, dan kreatif. Olah kreatif pada bahasa bunyi membuahkan hasil kemampuan membuat komposisi musik baru bagi siswa yang dilaksanakan dengan aktif dan dalam suasana kebersamaan.

Penggunaan pendekatan pembelajaran yang dilakukan oleh para peserta PPL selama proses mengajar musik berbasis kearifan lokal degung, berkisar pada pendekatan experience learning atau belajar melalui pengalaman, cooperative learning atau belajar berkelompok serta apresiasi pada saat memperkenalkan suatu kejadian musikal melalui media audiovisual. Pendekatan ini dilaksanakan dan tampak ketika para peserta PPL mengajar degung. Pada permainan musik degung, para siswa diajar langsung mengalami melalui metode imitasi dari demonstrasi yang dilaksanakan guru.

Selain pendekatan tersebut, para peserta Program Pengalaman Lapangan juga mempergunakan suatu pendekatan bernuansa kearifan lokal, dengan bim-

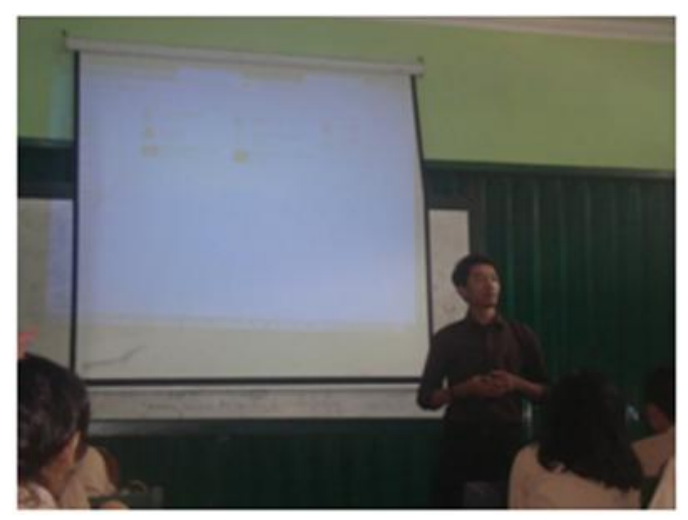

Gambar 3.

Media Audiovisual sebagai sarana apresiasi yang digunakan peserta PPL mengajar di SMA Pasundan 8 Bandung) (Dokumen Diah Latifah. 8 Mei 2014) 


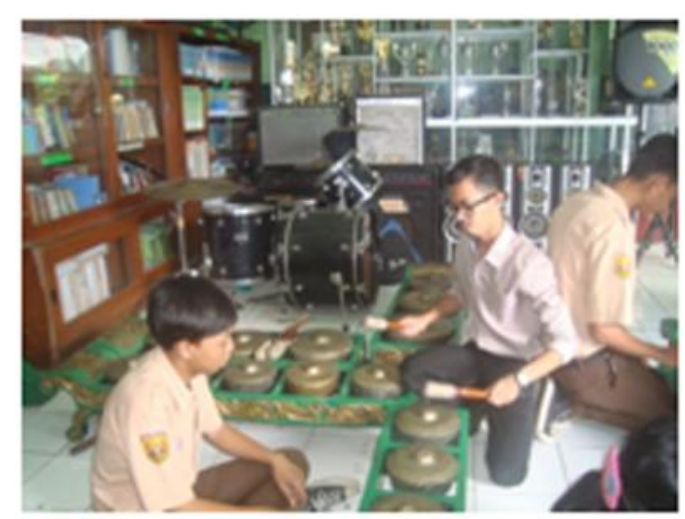

Gambar 4.

Proses Pembekalan Hard Skill Bermain Degung Melalui Pendekatan Berbasis Pengalaman dan Metode Demonstrasi, Imitasi dan teknik Ngabeo oleh Peserta PPL ke siswa (Dokumen Diah Latifah. 2 April 2014)

bingan langsung guru pamong. Guru pamong bersama sama dengan peserta PPL yang bertindak sebagai pengajar, mendemonstrasikan terlebih dahulu, dan siswa kemudian menirukanya, sambil menyanyikannya. Proses mengajar ini sering diistilahkan dengan kegiatan ngabeo, atau menirukan pola tabuh yang dimainkan guru disertai dengan menyanyikan nada yang dipukul. Pendekatan yang dilakukan lebih bersifat ketauladanan dalam bersikap. Sikap dalam hal ini adalah pendekatan afektif yang ditekankan oleh guru pamong yaitu sikap etika terhadap sesamanya sebagai manusia Sunda. Saat bermain degung, etika Sunda diaplikasikan, pada saat itu para pemain degung, mempraktikan pola perilaku silih asih (saling menyayangi), silih asah (saling mengajar), dan (silih asuh) saling membimbing. Pembimbing utama adalah guru, dan siswa yang lebih berkompeten mengajar teman sebayanya tanpa rasa sombong, Silih Asuh adalah perilaku saling menghargai bersifat afektif tetapi dapat pula bersifat psiko- motor ketika mereka saling menjaga pola permainan degung yang didukung rasa musikal. Saling menjaga tampak dari pola bermain degung, berwujud saling waspada dalam kasih sayang, menjaga temannya supaya tidak berbuat salah ketika menabuh. Ketika siswa menghadapi instrumen musik (waditra) degung mereka berperilaku sopan dan penuh etika dengan kesadaran pribadi, sebagai lambang penghormatan mereka terhadap warisan tradisi bernilai kearifan lokal. Tindakan untuk tidak melangkahi waditra waditra ini, ditampakan dengan perilaku, rela berjalan memutar agar tidak melangkahi waditra degung. Kompetensi afektif yang dipergunakan untuk memperkuat kognitif dan psikomotor dan tampak adalah sikap-sikap: disiplin. Para peminat mata pelajaran degung, sebelum bel waktu belajar, mengantri untuk mendapatkan gilirannya, mereka merasa senang, memiliki antusias tinggi mempelajari degung. Dalam bermain degung, guru yang menjadi suri tauladan, menjadikan siswa bertanggung jawab memainkan karya karawitan dengan aturan aturan cara bermain degung yang benar. Siswa mampu bekerja sama ketika bermain degung sesuai struktur musiknya, misalnya pola ritmik

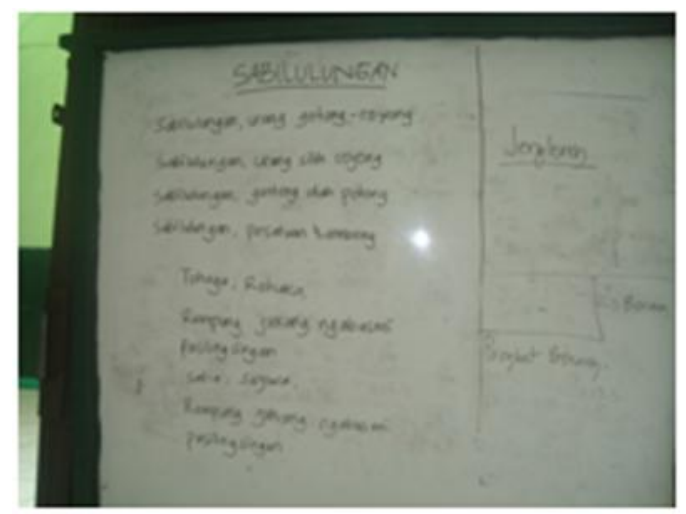

Gambar 5.

Dokumentasi Syair Lagu Sabilulungan (Dokumentasi Diah Latifah. 9 April 2014) 
kendang harus sesuai dengan aturan, menjaga pola irama, kalau kendang salah seluruh pola tabuh menjadi rusak. Demikian pula apabila penabuh goong salah musik menjadi rusak, sebagai contoh, apabila pada suatu saat kalimat musik menunjukkan akan selesai yang diarahkan tepakan kendang, karena goong salah ditabuh maka alur musik sulit untuk menyelesaikan kalimatnya. Kegiatan ini menanamkan rasa saling menghargai dan tidak mementingkan diri sendiri. Untuk memainkan karya degung, setiap bagian pada pola permainan setiap instrumen, dimainkan dengan memberikan ruang pada pemain lain dalam struktur musik, dengan keselarasan rasa musik, kebersamaan, dan saling menghargai. Kalau rasa ini tidak tercipta, struktur musik degung sulit untuk mencapai tujuan estetiknya. Hal ini diperlukan, karena karya ensambel degung bersifat poli ritmis, dan saling melengkapi, untuk menghasilkan permainan musik degung yang laik dalam estetika musik degung tradisi Sunda. Rasa ingin tahu menjadi perilaku kebiasaan yang tersirat. Siswa secara antusias dan aktif selalu menanyakan berbagai masalah yang mereka temui ketika mengalami kesulitan saat bermain degung. Misalkan pola menabuh Bonang, yang jatuh pada ketukan arsis (tidak bertekanan) dan interlocking dengan kenong, sering menjadi perhatian utama para penabuh (siswa).

Para siswa yang antusias ingin memiliki kemampuan bermain kendang, berkalikali meminta pendapat dan bimbingan untuk menabuh dengan tepakan kendang yang benar (memakai pemukul ataupun dengan teknik tepakan). Nilai kejujuran ditampakkan ketika para penabuh masih belum bisa memainkan beberapa waditra yang dirasa sulit. Mereka tanpa malu menanyakan kesulitan yang mereka hadapi pada temannya yang telah mampu memainkanya, atau pada guru pembimbing dan para peserta PPL sebagai guru praktik.

Beberapa karya yang teramati dan dimainkan pada musik degung adalah lagu "Manuk Dadali", "Sabilulungan" dan "Karatagan Pahlawan". Guru mata pelajaran Seni Budaya bidang musik (guru pamong), memberikan ceramah mengenai makna dari lagu tersebut, dan simbol apa yang ditanamkan dalam teks lagu sesuai dengan kearifan lokal tatar Pasundan. Penanaman Nilai kejuangan, tanpa kenal lelah, tidak pernah menyerah sampai suatu maksud (tujuan) berhasil yang dipaparkan dalam karya Manuk Dadali, dan Karatagan Pahlawan. Pemaknaan ini diserap oleh siswa. Lagu Sabilulungan dipaparkan oleh guru pamong, sebagai suatu norma orang Sunda yang suka bekerja sama, gotong royong, dan lambang persatuan, bahwa silaturahmi harus dijaga. Dengan silaturahmi serta semangat bekerja sama dan gotong royong, diyakini masyarakat Sunda untuk mencapai tujuan yang diinginkan.

Setiap siswa dengan seksama dan antusias berperan serta dalam praktik musik pada alur musik yang harus dimainkan, misalkan siswa yang bermain sebagai penjaga arkuh lagu memainkanya dengan tertib dan disertai dengan kesadaran rasa musikal yang baik. Begitu juga pemain goong, yang bertugas menjaga jatuhnya pengkalimatan lagu, bermain dengan penuh perhatian, agar pengkalimatan lagu berjalan dengan baik.

Kurikulum yang diimplementasikan dalam proses pembelajaran di SMA Pasundan 8 Bandung, masih mengikuti Kurikulum Tingkat Satuan Pendidikan tahun 2006.

Dari hasil pengamatan dan dokumentasi yang dilaksanakan, para peserta PPL mengalami penguatan keterampilan peng- 
gunaan pendekatan pembelajaran secara signifikan, terutama ketika mengalami aplikasi pengunaan pembelajaran kearifan lokal berkonsep silih asih, silih asah, silih asuh, yang berdampak pada penguatan aspek afektif berbasis kearifan lokal Sunda bagi peserta PPL. Mereka mengalami penguatan kemampuan mengajarkan musik degung, yang disertai dengan penanaman nilai-nilai kemanusiaan berbasis budaya Sunda. Di samping memperkuat keterampilan pendekatan pembelajaran berbasis kearifan lokal, pembiasaan penggunaan pendekatan pembelajaran aktif, apresiatif, berbasis pengalaman, belajar kooperatif, dan kreatif dengan konsep Barat, mengantarka para peserta PPL menjadi calon guru berkompeten. Mereka dengan lancar mengajar musik, mempergunakan keempat pendekatan tersebut, tanpa keraguan dan bahkan terkesan telah menjadi kebiasaan saat mengajar. Hasil ini menyatakan bahwa kombinasi penggunaan pendekatan pembelajaran berkonsep Barat dan kearifan lokal memperkuat kompetensi mengajar para peserta PPL dan memperkuat karakter positif berbasis budaya Sunda.

\section{SIMPULAN}

Penggunaan pendekatan pembelajaran berkonsep Barat yang diimplementasikan adalah penggunaan pendekatan pembelajaran berbasis pengalaman, aktif, kreatif, apresiasi melalui media audio dan audiovisual serta Cooporeatif Learning.

Pendekatan yang dilaksanakan khusus pada pembekalan materi musik degung berbasis kearifan lokal Sunda memiliki kekhususan. Pendekatan lebih bersifat afektif, dengan istilah Silih Asah, Silih Asih, Silih Asuh, yang akhirnya memperkuat kompetensi kognitif, afektif, dan psikomotor dalam bermain degung. Seperti yang dipaparkan dalam pembahasan dan pendahuluan, Silih Asih, Silih Asah, dan Silih Asuh dapat diasosiasikan sebagai teori kognitif pada pembelajaran, yang diawali melalui ketauladanan, merupakan pendekatan bernuansa afektif, berupa sikap berperilaku guru pamong, yang menerapkanya langsung pada saat proses pembelajaran degung berlangsung.

Kombinasi dua pendekatan dengan konsep Barat dan konsep kearifan lokal, memiliki keunggulan, terbukti telah mengantarkan para peserta PPL menjadi calon guru yang memiliki kemampuan menerapkan pendekatan pembelajaran musik dengan baik, dan yang lebih utama, bagi siswa, kombinasi pendekatan pembelajaran berbasis kearifan lokal dan berkonsep Barat, mengantarkan siswa memiliki kompetensi yang baik dalam praktik musik baik tradisi Barat maupun berbasis kearifan lokal, yang disertai dengan kompetensi afektif yang baik, mampu bersikap sesuai dengan normanorma kehidupan tradisi Sunda yang memiliki nilai dan norma kemanusiaan yang tinggi.

Metode pembelajaran yang digunakan saat proses pembelajaran di antaranya; metode praktik, metode imitasi, dan demonstrasi yang dilengkapi dengan metode ceramah saat para peserta praktik pengalaman lapangan mengajar praktik musik baik dalam musik tradisi Barat maupun tradisi muatan lokal Sunda, dalam hal ini Instrumen degung.

Keterbatasan dalam penggunaan pendekatan pembelajaran berkonsep kearifan lokal khususnya tatar Sunda, adalah kebermaknaan dari nilai-nilai kearifan lokal yang tersembunyi di balik pendekatan tersebut, secara umum hanya akan efektif disampaikan pada pendukung budaya kearifan lokal yang bersangkutan, disampaikan oleh 
individu yang benar-benar menghayati dan memahami nilai yang terkandung di dalamnya. Kearifan lokal Sunda akan sulit diterapkan pada penganut kearifan lokal lain, sebelum penganut atau pendukung kearifan lokal lain memahami makna yang terdapat dalam kearifan lokal Sunda.

\section{Catatan Akhir}

Penelitian yang mengkaji implementasi kurikuler khususnya implementasi kuri-kuler untuk mempersiapkan calon guru seni budaya bidang musik dalam mem-perkuat nilai-nilai budaya bangsa masih jarang dilakukan. Hal ini perlu ditindak lanjuti dengan penelitian sejenis dibidang seni yang lain, baik bidang seni rupa, seni tari, maupun seni teater. Mempersiapkan calon guru dengan kompetensi yang memadai dan memiliki karakter berbasis budaya bangsa penting untuk dilaksanakan, karena diyakini nilai-nilai luhur berbasis budaya Nusantara memiliki keunggulan dalam membentuk manusia yang berbudi luhur dan berperikemanusiaan, dengan argumentasi apabila guru berbudi luhur dan berperikemanusiaan, diharapkan mereka mengajarkan nilai-nilai yang dianutnya kepada para siswanya.

\section{Daftar Pustaka}

Diah Latifah

2014 Implementasi Kurikuler Mata Pelajaran Seni Musik Berbasis Budaya Sunda. Al Mizan. Bandung: Media Universitas Pasundan. ISSN 0852-839X. Edisi No 149/Juni 2014.

M. Jazuli

2008 Paradigma Kontekstual Pendidikan Seni. Surabaya: Unesa University Press

Ni Wyn Widiastuti, I G. A. Suhandana, N Dantes.

2013 Studi Evaluasi Efektivitas Pelaksanaan Praktik Pengalaman La- pangan (PPL) Mahasiswa Fakultas Pendidikan Olahraga Dan Kesehatan (FPOK) IKIP PGRI Bali Tahun 2012. e-Journal Program Pascasarjana Universitas Pendidikan Ganesha Program Studi Administrasi Pendidikan (Volume 4 Tahun 2013)

Nuh, M,

2013 Buku Guru Seni Budaya. Jakarta: Kementerian Pendidikan dan Kebudayaan

Sharan, Shlomo.

2012 The Handbook Of Cooperative Learning. Yogyakarta: Familia

Slavin, Robert E.

2008 Cooperatif Learning. Bandung: Nusa Media

Wina Sanjaya

2008 Strategi Pembelajaran. Jakarta: Kencana Prenada Media Group

\section{Sumber lain:}

Kährika, Pille, Äli Leijena,b, ${ }^{*}$, Tuulike Kivestua.

2012 Developing music listening skills using active learning methods in secondary education. Procedia Social and Behavioral Sciences 45 (2012) 206 - 215. Doi 10.1016/j.sbspro. 2012.06.557. Available online at www.sciencedirect.com

Scott, Sheila.

2011 Contemplating a Constructivist Stance for Active Learning within Music Education. Arts Education Policy Review, 112: 191-198, 2011. Copyright C _ Taylor \& Francis Group, LLC ISSNN: 1063-2913 print / 1940-4395 online DOI: 10.1080/ 10632913.2011.592469 